Original article

UDC 597.554.3. 591.134

https://doi.org/10.24143/2073-5529-2021-4-46-56

\title{
Growth of tench (Tinca tinca L., 1758) (Cyprinidae) in reservoirs of K. Satpayev canal
}

\author{
Vladimir N. Krainyuk ${ }^{1}$, Saule Zh. Assylbekova ${ }^{2}$, Azis V. Shutkarayev $^{3}$ \\ ${ }^{1-3}$ Fisheries Research and Production Center, LLP, \\ Almaty, Republic of Kazakhstan, assylbekova@mail.ru
}

\begin{abstract}
The reservoirs of the K. Satpayev canal are the important fishery water bodies in the Central Kazakhstan. Some of these reservoirs are inhabited by tench, a fish species relatively widely represented in other water systems of the region. In the reservoirs of the canal this species is not the main commercial one but it has a fairly high commercial value due to its popularity with consumers. As part of the research, the growth indicators of Tinca tinca from 4 reservoirs were evaluated, and the data on its growth from 3 more reservoirs were also provided. These samples differ in efficiency and growth rates. It has been found that there is no sexual or generation variability. Growth rates in successive fish generations strongly correlate with each other, which may indirectly indicate the stability of living conditions. The R. Lee's phenomenon was not marked. In this regard, the calculation of variables of the von Bertalanffy growth equation was carried out without additional data processing. The highest rates of linear growth were characteristic of Tinca tinca from the reservoir of HS No. 9. However, the effectiveness of its growth scheme was the lowest. Population with a longer age range from the reservoir HS No. 3 did not have high linear growth rates, but its growth efficiency was higher. In this case, it is obvious that any assessment of growth will be relative and depend on the goals set for it. In the reservoirs of the canal there are more or less similar conditions for tench populations living due to the specifics of its functioning. The main limiting factor for the growth rate, in our opinion, will be abundance of the species in the reservoir and related trophic factors with a certain influence of withdrawal (fishing, predators).
\end{abstract}

Keywords: the K. Satpayev Canal, reservoir, tench, population, growth, age, linear-weight ratio, weight, increase

Acknowledgment: this research is funded by the Ministry of Ecology, Geology and Natural Resources of the Republic of Kazakhstan (Grant No. BP10264205 Comprehensive evaluation of fishery resourses and hydrobionts of water basins of Kazakhstan and development of evidence-based recommendations for their sustainability).

For citation: Krainyuk V. N., Assylbekova S. Zh., Shutkarayev A. V. Growth of tench (Tinca tinca L., 1758) (Cyprinidae) in reservoirs of K. Satpayev canal. Vestnik of Astrakhan State Technical University. Series: Fishing Industry. 2021;4:46-56. (In Russ.) https://doi.org/10.24143/2073-5529-2021-4-46-56.

Научная статья

\section{Рост линя Tinca tinca (L., 1758) (Cyprinidae) в водохранилищах канала имени К. Сатпаева}

\author{
Владимир Николаевич Крайнюк ${ }^{1}$ Сауле Жангировна Асылбекова ${ }^{2}$, \\ Азис Васильевич Шуткараев \\ ${ }^{1-3}$ Научно-производственный центр рыбного хозяйства, \\ Алматы, Республика Казахстан, assylbekova@mail.ru凶
}

Аннотация. Водохранилища канала имени К. Сатпаева являются важными рыбопромысловыми водоемами в Центральном Казахстане. Ряд этих водохранилищ населяет линь - вид относительно широко представленный в других водных системах региона. В водохранилищах канала этот вид не является основным промысловым, но имеет достаточно высокую коммерческую ценность из-за его популярности у потребителей. В рамках проведенных исследований были оценены показатели роста у линей из 4 водохранилищ, а также приведены данные по его росту еще из 3 водоемов канала. Эти выборки различаются по эффективности и темпам роста. Было выявлено, что половая и генерационная изменчивость отсутствует. Показатели роста в смежных поколениях достаточно сильно коррелируют между собой, что косвенно может свидетельствовать о стабильности условий обитания. Феномен Р. Ли отмечен не был, в связи с этим расчет переменных уравнения фон Берталанфи осуществлялся без дополнительной подготовки данных. Наибольшие темпы линейного роста были характерны для линей из вдхр. ГУ № 9. Однако эффективность его схемы роста была самой низкой. Популяция с более длинным возрастным рядом из вдхр. ГУ № 3 не обладала высокими темпами линейного роста, но эффективность ее роста была выше. В данном случае очевидно, что любая 
оценка роста будет относительна и будет зависеть от целей, поставленных перед ней. В водохранилищах канала, ввиду специфики его функционирования, складываются более-менее одинаковые условия для существования популяций линя. Основным лимитирующим темпы роста фактором, по нашему мнению, будет обилие вида в водоеме и связанные с ним трофические факторы при определенном влиянии изъятия (промысел, хищники).

Ключевые слова: канал им. К. Сатпаева, водохранилище, линь, популяция, рост, возраст, линейно-весовые соотношения, вес, прирост

Благодарности: исследование финансируется Министерством экологии, геологии и природных ресурсов Республики Казахстан (грант № ВР10264205 «Комплексная оценка рыбных ресурсов и гидробионтов водных бассейнов Казахстана и разработка научно обоснованных рекомендаций по их устойчивости»).

Для цитирования: Крайнюк В. Н., Асылбекова С. Ж., Шуткараев А. В. Рост линя Tinca tinca (L., 1758) (Cyprinidae) в водохранилищах канала имени К. Сатпаева // Вестник Астраханского государственного технического университета. Серия: Рыбное хозяйство. 2021. № 4. С. 46-56. https://doi.org/10.24143/2073-5529-2021-4-46-56.

\section{Introduction}

Central Kazakhstan region is classified as waterdeficient. For its stable water supply, K. Satpayev canal was built in the 60s of the last century (formerly IrtyshKaraganda). It connected Irtysh basin with drainless rivers of the region. 13 reservoirs with a total area of $273 \mathrm{~km}^{2}$ have been built on the canal route. Since their construction, they have been used for fishing. Currently, these reservoirs are of high fishery importance.

Tench is not the ground of fishery on the canal reservoirs. But, due to high demand, these species are popular object of catching. Recently [1], aspects of tench biology in the reservoirs of the canal were described. Its populations were assessed as stable and having a tendency to increase the number and expansion of water habitats. Indeed, at present there is information about tench catching in other reservoirs (in particular, HS No. 7). The empirical growth was also evaluated although not in all cases correctly, since for large tench with thickenings on operculum, this is still quite a laborious task.

This work shows the data on calculated growth of tench in the reservoirs of the canal. An attempt is made to assess both intergroup and intra-group variability of growth rates.

It is worth noting that these species rarely come to the attention of researchers studying growth and development [2-13]. Nevertheless, with the increase in both production of aquaculture which also includes this species, and the intensification of fishing, it poses the task of a comprehensive assessment of its biology.

\section{Materials and methods of research}

The material was collected during field trips in 20122016. Stationary gill nets were used for trapping. Standard measurements were made (length, body weight, carcass, etc.) [14]. Gill covers (operculum) were used to determine the age and back calculation of growth [15].

The calculation was carried out by the Dahl-Lea method of simple back calculations [16]. According to the research of L. S. Ivanov (1964) (quoted by: [17]) the use of direct proportions gives a more correct result. The growth gain was determined by natural values $[18,19]$.
The constants of Bertalanffy equation (hereinafter referred to as VBGE) were calculated using the variables $\alpha$ and $\beta$ of the Ford-Walford equation. The asymptotic length $L_{\infty}$, the growth constant k and the "initial age" $t_{0}$ were determined [20]. Based on the obtained indicators, the Poly-Munro growth performance index (GPI) is determined [21].

As the initial data for the above indicators and to prevent the influence of the R. Lee phenomenon (we assume the same growth features for operculum as for scales), the results of the reverse calculation of growth by the Vaughan-Burton method or so-called "last mark" are sometimes used [22]. However, in the course of work it was revealed that such a methodical approach leads in some cases to distortion of the results. In this regard, preliminary values in the age group of "yearlings" (containing data from several generations) were subjected to a variance analysis which showed no differences between generations within this age.

Weight growth was calculated based on linearweight ratios using the Hilborn-Waters method [23] based on the formulas:

$$
\begin{gathered}
w(t)=w_{\infty}\left(1-e^{(-k(t-t 0)) b}\right) ; \\
w_{\infty}=a \cdot L_{\infty}{ }^{b},
\end{gathered}
$$

where: $w_{\infty}$ is asymptotic weight of the carcass; $e$ is exponent $(\sim 2.718)$.

The constants $k, t_{0}$ are determined from the Bertalanffy equation, the coefficients $a$ and $b$ are determined by the linear-weight relationships (LWR).

Linear-weight relationships (LWR) were determined by R. Frose [24]. The ratio of weight and body length was analyzed by basic transformed equation of linear-weight dependence:

$$
w=a \cdot L^{b},
$$

where: $w$ is the weight of the trunk; $L$ is the length of the body; $a$ and $b$ are the coefficients of equation.

It was the trunk weight that was used, and not the body weight completely because this indicator forms a more reliable equation. Accordingly, the weight growth was determined for the weight of the trunk. 
These statistical calculations, although they cause skepticism [25], but give some ground for analytical thinking.

Calculation of the specific growth rate of Schmalhausen-Brody was carried out according to generally accepted formula [18].

The obtained data were statistically processed according to N. A. Plokhinsky [26] using MS Excel 2003 program [27]. Variance (ANOVA), correlation and hierarchical analyses were performed using IBM SPSS v. 22 program [28]. Significant differences were recognized for analysis of variance at a confidence level of $\alpha \leq 0.05$. For correlation analysis: at $\alpha \leq 0.01$ for calculated growth and $\alpha \leq 0.05$ for increments.
In addition to the standard ones, the following abbreviations and designations are used in this work: vdhr. - reservoir, HS - hydrosystem, $F$ - value of the Fisher criterion, $\sigma-$ standard deviation. Designation of increments was carried out according to the following scheme: after the symbol $G$, the age was indicated, $G_{02}$ - the growth gain in the second year of life, etc. The index " $C$ " denoted the specific growth rate according to Schmalhausen-Brody, age was indicated in the same way as for gains, $Q_{C}$ - fatness according to Clark.

\section{Research results}

As can be seen from Table 1, the tench inhabits quite diverse reservoirs of the canal.

General characteristics of the canal reservoirs

\begin{tabular}{|c|c|c|c|c|c|c|c|}
\hline \multirow{2}{*}{ Reservoirs } & \multirow{2}{*}{ Area, ha } & \multirow{2}{*}{ Length, km. } & \multirow{2}{*}{ Width, km } & \multicolumn{2}{|c|}{ Depth, m } & \multirow{2}{*}{$\begin{array}{c}\text { Volume of water, } \\
\text { million } \mathbf{~ m}^{3}\end{array}$} & \multirow{2}{*}{$\begin{array}{c}\text { The sample volume, } \\
\text { specimen }\end{array}$} \\
\hline & & & & medium & maximum & & \\
\hline Ekibastuzskoe & 720 & 4.5 & 2.8 & 2.4 & 13.4 & 17.29 & 5 \\
\hline HS No.1 & 1090 & 16.0 & 1.6 & 7.6 & 25.7 & 83.70 & 7 \\
\hline HS No. 2 & 130 & 1.3 & 0.5 & 1.2 & 7.5 & 1.73 & 4 \\
\hline HS No. 3 & 1380 & 6.8 & 2.3 & 3.2 & 15.5 & 45.30 & 21 \\
\hline HS No.4 & 1210 & 6.1 & 2.6 & 4.6 & 17.3 & 56.39 & 27 \\
\hline HS No.9 & 740 & $6.2 *$ & 2.0 & 3.4 & 11.5 & 30.42 & 82 \\
\hline HS No. 10 & 1790 & 8.2 & 3.5 & 3.9 & 13.1 & 70.61 & 25 \\
\hline
\end{tabular}

*Length along the riverbed.

Among them there are typically "floodplain" with a small proportion of depths above $4 \mathrm{~m}$. (Ekibastuzskoye, HS No. 2), there are typically "channel" type (HS No. 1) and various intermediate ones.

Tench is hardly caught at depths of more than $4 \mathrm{~m}$. Which is explained by its attachment to submerged vegetation such as rdests which rarely grow deeper. In this regard, the bathymetric characteristics of the reservoir for this species are important. In the thickets of the Canadian elodea which forms a continuous carpet along the bottom of the canal reservoirs, it does not live, at least on a permanent basis.

Hydrochemical regime of the canal reservoirs is relatively stable and is based on two components: chemical composition of the water of Irtysh River and local background including infiltration from the soil. As we move away from the sources, the latter plays an increasing role, increasing mineralization and a number of other indicators.

Table 2 shows the results of growth calculations for populations from 7 reservoirs of K. Satpayev Canal.

Table 2

Back calculation of linear growth of tench in the canal reservoirs

\begin{tabular}{|c|c|c|c|c|c|c|c|c|c|c|c|}
\hline \multirow{2}{*}{ Reservoirs } & \multicolumn{11}{|c|}{ Calculated height, $\mathrm{cm}$, by year } \\
\hline & 1 & 2 & 3 & 4 & 5 & 6 & 7 & 8 & 9 & 10 & 11 \\
\hline Ekibastuzskoe & 4.8 & 7.8 & 10.9 & 13.8 & 16.4 & 18.6 & 20.3 & - & - & - & - \\
\hline HS No. 1 & 5.0 & 8.0 & 11.8 & 14.7 & 15.7 & 21.0 & 23.2 & - & - & - & - \\
\hline HS No. 2 & 5.0 & 8.0 & 12.0 & 15.8 & 18.8 & 20.9 & 23.8 & 25.8 & - & - & - \\
\hline HS No. 3 & 5.1 & 8.0 & 11.2 & 14.1 & 17.2 & 20.0 & 22.2 & 24.3 & 26.2 & 27.9 & 29.8 \\
\hline HS No. 4 & 5.2 & 8.4 & 11.9 & 15.2 & 18.0 & 20.5 & 23.2 & 25.3 & 27.4 & - & - \\
\hline HS No. 9 & 5.0 & 8.5 & 12.7 & 16.2 & 19.3 & 21.4 & 23.3 & 25.2 & 26.9 & 28.3 & - \\
\hline HS No. 10 & 5.1 & 8.4 & 11.8 & 15.2 & 18.3 & 20.7 & 23.0 & 24.7 & 26.4 & 28.7 & - \\
\hline
\end{tabular}

Empirically, it can be seen that the tench from the Ekibastuz reservoir is characterized by the lowest growth rates, and the fastest - for individuals from the reservoir HS No. 2. Although, in fact it is quite difficult to determine the latter because of "uneven" growth over the years of life. Unfortunately, there are few materials $\dot{m}$ for the first three reservoirs. Therefore, further analysis has to be limited to the four remaining reservoirs.

A pair comparison by methods of variance analysis (ANOVA) showed accurately $(\alpha \leq 0.05)$ faster growth of the tench from the reservoir HS No. 9 and ranges from three years to six or nine depending on comparison pair. Growth of individuals from the reservoirs of hydrosystems No. 4 and No. 10 was approximately the same with a single case of differentiation at the age of eight years. The tench from reservoir of HS \#3 grew reliably the worst of all but they had the most stretched age range.

Table 3 contains information on back calculation of growth for individual generations. 
Back calculation of generation growth

\begin{tabular}{|c|c|c|c|c|c|c|c|c|c|c|c|c|}
\hline \multirow{2}{*}{ Reservoir } & \multirow{2}{*}{ Generation } & \multicolumn{11}{|c|}{ Calculated dimensions by years of life, $\mathrm{cm}$} \\
\hline & & 1 & 2 & 3 & 4 & 5 & 6 & 7 & 8 & 9 & 10 & 11 \\
\hline \multirow{6}{*}{ Reservoir HS No. 3} & 2005 & 5.7 & 8.0 & 10.3 & 12.6 & 16.0 & 19.5 & 21.7 & 24.0 & 26.3 & 27.6 & 29.8 \\
\hline & 2006 & 5.0 & 7.9 & 11.4 & 13.9 & 17.1 & 20.0 & 22.2 & 24.3 & 25.9 & 27.8 & - \\
\hline & 2007 & 5.2 & 8.0 & 11.0 & 13.9 & 17.0 & 19.8 & 22.2 & 24.4 & 26.3 & - & - \\
\hline & 2008 & 5.4 & 8.4 & 11.8 & 15.1 & 17.8 & 20.3 & 22.2 & 24.5 & - & - & - \\
\hline & 2009 & 5.0 & 8.0 & 11.3 & 14.9 & 17.7 & 20.1 & 22.0 & - & - & - & - \\
\hline & 2011 & 3.6 & 7.1 & 10.2 & 14.3 & 16.8 & - & - & - & - & - & - \\
\hline \multirow{6}{*}{ Reservoir HS No. 4} & 2005 & 6.1 & 9.1 & 12.3 & 15.8 & 18.7 & 21.5 & 23.7 & 25.4 & 27.5 & - & - \\
\hline & 2006 & 5.7 & 8.4 & 11.8 & 15.5 & 18.0 & 21.0 & 23.4 & 25.4 & 27.3 & - & - \\
\hline & 2007 & 5.5 & 8.9 & 11.9 & 15.4 & 18.2 & 20.9 & 23.3 & 25.1 & - & - & - \\
\hline & 2008 & 4.8 & 8.0 & 12.0 & 14.7 & 17.7 & 20.0 & 23.6 & - & - & - & - \\
\hline & 2009 & 5.4 & 8.4 & 12.4 & 15.6 & 18.3 & 20.0 & - & - & - & - & - \\
\hline & 2010 & 4.6 & 8.1 & 10.7 & 14.3 & - & - & - & - & - & - & - \\
\hline \multirow{8}{*}{ Reservoir HS No. 9} & 2004 & 5.1 & 9.0 & 12.9 & 15.5 & 19.4 & 21.7 & 23.4 & 25.3 & 26.9 & 28.3 & - \\
\hline & 2006 & 5.4 & 8.8 & 13.1 & 16.8 & 20.1 & 21.9 & 23.3 & 24.5 & - & - & - \\
\hline & 2007 & 5.3 & 8.9 & 13.0 & 16.5 & 19.4 & 21.5 & - & - & - & - & - \\
\hline & 2008 & 4.7 & 7.7 & 11.7 & 16.1 & 19.2 & 21.3 & 23.5 & 25.4 & - & - & - \\
\hline & 2009 & 4.5 & 7.3 & 11.4 & 15.7 & 19.4 & 21.1 & 23.0 & - & - & - & - \\
\hline & 2010 & 4.7 & 8.2 & 12.5 & 15.9 & 18.8 & 21.1 & - & - & - & - & - \\
\hline & 2011 & 5.1 & 8.7 & 13.0 & 16.0 & 19.1 & - & - & - & - & - & - \\
\hline & 2012 & 3.9 & 6.6 & 13.2 & 16.5 & - & - & - & - & - & - & - \\
\hline \multirow{10}{*}{ Reservoir HS No. 10} & 2003 & 5.7 & 9.2 & 12.1 & 15.5 & 17.8 & 20.1 & 22.4 & 24.1 & 26.4 & 28.7 & - \\
\hline & 2004 & 5.7 & 8.8 & 11.6 & 15.0 & 18.5 & 20.4 & 23.0 & 24.7 & - & - & - \\
\hline & 2005 & 4.9 & 8.4 & 12.2 & 15.0 & 18.2 & 20.8 & 23.0 & 24.7 & - & - & - \\
\hline & 2006 & 5.9 & 8.8 & 12.4 & 15.6 & 19.2 & 21.6 & - & - & - & - & - \\
\hline & 2007 & 4.7 & 7.7 & 11.5 & 14.7 & 18.0 & 20.9 & 23.5 & - & - & - & - \\
\hline & 2008 & 4.9 & 7.3 & 10.4 & 15.2 & 18.3 & 20.7 & 23.2 & - & - & - & - \\
\hline & 2009 & 5.0 & 8.6 & 11.8 & 14.7 & 17.1 & 20.3 & - & - & - & - & - \\
\hline & 2010 & 5.4 & 9.0 & 12.2 & 15.8 & 18.2 & - & - & - & - & - & - \\
\hline & 2011 & 5.3 & 8.6 & 11.6 & 15.3 & - & - & - & - & - & - & - \\
\hline & 2012 & 4.8 & 7.2 & 10.8 & - & - & - & - & - & - & - & - \\
\hline
\end{tabular}

The analysis of variance shows practically no differentiation between the generations. There were only two cases when the reliability of differences was at the level of $\alpha \leq 0.05$. One is for reservoir of HS No. 4 (at 6 years old) and one for the reservoir of HS No. 9 (in 2 years). The group of reservoirs of HS No. 4 showed relatively increased growth rates during the study period. But there was also a picture of a drop in growth rates on the timeline. However, only at the level of trends that is not verified by statistical methods.

There is no sexual variability of growth (Table 4).

Sexual variability of tench growth

\begin{tabular}{|c|c|c|c|c|c|c|c|c|c|c|c|}
\hline \multirow{2}{*}{ Reservoir } & \multirow{2}{*}{ Sex } & \multicolumn{10}{|c|}{ Calculated height, cm, by year } \\
\hline & & 1 & 2 & 3 & 4 & 5 & 6 & 7 & 8 & 9 & 10 \\
\hline \multirow{3}{*}{ Reservoir HS No. 3} & Females & 5.0 & 7.7 & 11.0 & 14.0 & 17.1 & 19.8 & 22.1 & 244 & 26.4 & 28.4 \\
\hline & Males & 5.2 & 8.2 & 11.4 & 14.3 & 17.3 & 20.1 & 22.2 & 24.3 & 25.9 & 27.8 \\
\hline & ANOVA, F & 0.33 & 1.93 & 1.34 & 0.34 & 0.32 & 0.90 & 0.25 & 0.15 & 2.53 & 1.07 \\
\hline \multirow{3}{*}{ Reservoir HS No. 4} & Females & 5.4 & 8.5 & 12.0 & 15.2 & 18.2 & 20.8 & 23.2 & 25.4 & 27.5 & - \\
\hline & Males & 5.2 & 8.3 & 11.9 & 15.2 & 18.0 & 20.4 & 23.3 & 25.3 & 27.2 & - \\
\hline & ANOVA, F & 0.42 & 0.25 & 0.09 & 0.01 & 0.38 & 1.62 & 0 & 0.13 & 0.16 & - \\
\hline \multirow{3}{*}{ Reservoir HS No. 9} & Females & 5.0 & 8.4 & 12.7 & 16.2 & 19.3 & 21.4 & 23.2 & 24.8 & 26.3 & 28.5 \\
\hline & Males & 5.1 & 8.5 & 12.6 & 16.1 & 19.2 & 21.3 & 23.4 & 25.7 & 27.1 & 28.1 \\
\hline & ANOVA, F & 0.08 & 0.07 & 0.08 & 0.26 & 0.14 & 0.50 & 0.37 & 3.41 & 1.26 & - \\
\hline \multirow{3}{*}{$\begin{array}{l}\text { Reservoir HS No. } \\
10\end{array}$} & Females & 5.2 & 8.3 & 11.6 & 15.1 & 18.4 & 20.9 & 23.1 & 24.4 & - & - \\
\hline & Males & 5.3 & 8.6 & 12.0 & 15.3 & 18.1 & 20.6 & 22.9 & 24.8 & - & - \\
\hline & ANOVA, F & 0.62 & 0.39 & 0.19 & 0.52 & 0.60 & 0.53 & 0.46 & 0.12 & - & - \\
\hline
\end{tabular}

In general, the difference between the sexes in terms of growth rates should be linked either with peculiarity of species reproductive strategies and/or features of ethology [29-31] which are not shown in tench, or with pessimal habitat conditions [32].
Analyzing correlations in successive year classes in the tench from reservoirs of the canal (Table 5), it is worth recognizing that continuity of the growth in the generations is quite strong. 
Correlation of calculated values of body length in successive year classes (reliable values are emphasized at $\alpha \leq 0.01$ )

\begin{tabular}{|l|c|c|c|c|c|c|c|c|c|}
\hline \multirow{2}{*}{ Water reservoir } & \multicolumn{9}{|c|}{ Pearson correlation indicators } \\
\cline { 2 - 10 } & $\mathbf{1 / 2}$ & $\mathbf{2 / 3}$ & $\mathbf{3 / 4}$ & $\mathbf{4 / 5}$ & $\mathbf{5 / 6}$ & $\mathbf{6 / 7}$ & $\mathbf{7 / 8}$ & $\mathbf{8 / 9}$ & $\mathbf{9 / 1 0}$ \\
\hline HS No. 3 & $\underline{0.870}$ & $\underline{0.773}$ & $\underline{0.755}$ & $\underline{0.832}$ & 0.553 & $\underline{0.679}$ & 0.610 & $\underline{0.907}$ & 0.913 \\
\hline HS No. 4 & $\underline{0.793}$ & 0.441 & $\underline{0.779}$ & $\underline{0.833}$ & $\underline{0.628}$ & $\underline{0.696}$ & 0.735 & 0.621 & - \\
\hline HS No. 9 & $\underline{0.698}$ & $\underline{0.538}$ & $\underline{0.617}$ & $\underline{0.641}$ & $\underline{0.719}$ & 0.667 & 0.795 & 0.831 & - \\
\hline HS No. 10 & $\underline{0.702}$ & $\underline{0.695}$ & 0.431 & $\underline{0.670}$ & $\underline{0.861}$ & 0.782 & 0.164 & - & - \\
\hline
\end{tabular}

This is especially evident for the first years of life up to about 6th year.
Annual increases in physical terms, in general, logically decrease as the age increases (Table 6).

Annual natural growth gain $(G, \mathrm{~cm})$, their mean-square deviation $\left(\sigma_{G}\right)$ and specific growth rate $(C)$

\begin{tabular}{|c|c|c|c|c|c|c|c|c|c|c|c|}
\hline \multirow{2}{*}{ Reservoirs } & \multirow{2}{*}{ Parameters } & \multicolumn{10}{|c|}{ Years of life } \\
\hline & & 2 & 3 & 4 & 5 & 6 & 7 & 8 & 9 & 10 & 11 \\
\hline \multirow{3}{*}{ HS No. 3} & $G$ & 2.9 & 3.2 & 2.9 & 3.0 & 2.7 & 2.2 & 2.2 & 1.9 & 2.0 & 1.2 \\
\hline & $\sigma_{G}$ & 0.43 & 0.56 & 0.79 & 0.67 & 0.87 & 0.56 & 0.55 & 0.28 & 0.30 & - \\
\hline & $C$ & 0.457 & 0.341 & 0.232 & 0.196 & 0.148 & 0.105 & 0.095 & 0.075 & 0.073 & 0.041 \\
\hline \multirow{3}{*}{ HS No. 4} & $G$ & 3.2 & 3.5 & 3.2 & 2.8 & 2.5 & 2.3 & 1.9 & 1.9 & - & - \\
\hline & $\sigma_{G}$ & 0.63 & 1.11 & 0.75 & 0.65 & 0.73 & 0.49 & 0.36 & 0.48 & - & - \\
\hline & $C$ & 0.478 & 0.353 & 0.241 & 0.171 & 0.133 & 0.107 & 0.078 & 0.072 & - & - \\
\hline \multirow{3}{*}{ HS No. 9} & $G$ & 3.4 & 4.2 & 3.5 & 3.1 & 2.2 & 1.9 & 1.8 & 1.6 & 2.0 & - \\
\hline & $\sigma_{G}$ & 0.84 & 1.26 & 1.16 & 0.93 & 0.60 & 0.56 & 0.45 & 0.51 & 0.36 & - \\
\hline & $C$ & 0.530 & 0.407 & 0.248 & 0.177 & 0.108 & 0.084 & 0.073 & 0.062 & 0.071 & - \\
\hline \multirow{3}{*}{ HS No. 10} & $G$ & 3.2 & 3.3 & 3.4 & 3.1 & 2.5 & 2.4 & 1.8 & 2.3 & 2.3 & - \\
\hline & $\sigma_{G}$ & 0.61 & 0.63 & 0.81 & 0.84 & 0.65 & 0.50 & 0.41 & - & - & - \\
\hline & $C$ & 0.480 & 0.332 & 0.250 & 0.184 & 0.129 & 0.112 & 0.074 & 0.091 & 0.084 & - \\
\hline
\end{tabular}

But, they show quite strong deviations from this vector. The highest gains (if you do not take into account the first year of life) occur in the third or third and fourth year. In the reservoirs of the canal, its mass puberty occurs in the $4^{\text {th }}$ year of life. Thus, in fact, the highest growth rates are characteristic of the period preceding the formation of puberty which should probably be associated with hormonal changes in the body. This, in part, may explain the lower growth rates in the second year of life when there is no need for enhanced metabolism and accumulation of primary metabolites for production of higher-quality germ cells in the future, and other nuances of life are prioritized, such as, perhaps, greater migration mobility, the development and retention of new habitats, etc. Accordingly, the decrease in gains is also explained already at reproductive ages due to the permanent redirection of part of the energy flows to reproduction. In individuals skipping spawning, the growth gains increase [33].

The smallest variability of growth gain (by $\sigma$ ) occurs at older ages. Specific growth rates decrease throughout life. The sharpest drop in $\mathrm{C}$ indicator is typical for the tench from the reservoir of HS No. 9.

Analysis of variance showed no differences in the increments between generations and sexes, with the exception of a single case: Increments of the $4^{\text {th }}$ year in the reservoir of HS No. 9 were differentiated by generation. However, there were no patterns of decrease or increase in gains.

Individual gains are not related to each other. The four significant correlations shown in Table 7 can be attributed to randomness.

Correlation of individual natural annual increments of adjacent life spans (reliable values at $\alpha \leq 0.05$ are emphasized)

\begin{tabular}{|l|c|c|c|c|c|c|c|}
\hline \multirow{2}{*}{ Water reservoir } & \multicolumn{7}{|c|}{ Indicators of Pearson correlation of gains } \\
\cline { 2 - 8 } & $\boldsymbol{G}_{\mathbf{0 2}} / \boldsymbol{G}_{\mathbf{0 3}}$ & $\boldsymbol{G}_{\mathbf{0 3}} / \boldsymbol{G}_{\mathbf{0 4}}$ & $\boldsymbol{G}_{\mathbf{0 4}} / \boldsymbol{G}_{\mathbf{0 5}}$ & $\boldsymbol{G}_{\mathbf{0 5}} / \boldsymbol{G}_{\mathbf{0 6}}$ & $\boldsymbol{G}_{\mathbf{0 6}} / \boldsymbol{G}_{\mathbf{0 7}}$ & $\boldsymbol{G}_{\mathbf{0 7}} / \boldsymbol{G}_{\mathbf{0 8}}$ & $\boldsymbol{G}_{\mathbf{0 8}} / \boldsymbol{G}_{\mathbf{0 9}}$ \\
\hline HS No. 3 & -0.238 & 0.353 & -0.217 & 0.005 & -0.365 & -0.257 & 0.157 \\
\hline HS No. 4 & -0.388 & 0.267 & $\underline{0.539}$ & 0.212 & 0.196 & 0.518 & -0.058 \\
\hline HS No. 9 & -0.065 & -0.320 & -0.227 & -0.151 & 0.175 & 0.161 & 0.499 \\
\hline HS No. 10 & 0.217 & 0.073 & 0.027 & $\underline{0.571}$ & 0.477 & $\underline{0.945}$ & - \\
\hline
\end{tabular}

In any case, there is no rational explanation for them. It follows from the above that in these 4 groupings there are no divisions into clusters according to growth rates, i.e. intra-group variability is not clearly expressed. 
Tables 5 and 7 contain, at first glance, contradictory data. But, in fact, these are multi-level indicators. In the presence of statistically manipulating body size indicators in a certain period and growth rate, the relationship between them is not mandatory.

Individuals with high growth rates manifest them during the main life time. Those individuals who are lagging behind in growth rates will make attempts to catch up with them, but they will not be able to do it in full. The next increments of all groups may already be approximately equal but the digital growth indicators will still be different. It is quite logical that larger individuals have advantages in competition for resources.
This leads again to their increased growth rates. And that's why most of the laggards fail to break this circle and align with the leaders. Something similar has been described for perches using ethological data [34]. Large sizes give an advantage not only in trophic competition, but also in the "genetic footprint" left [35], and ensure its stability for population [32].

Presence or absence of a significant difference between the sizes of different generations at the same age including the phenomenon of R. Lee can be assessed by comparing them by methods of variance analysis (Table 8).

One-factor intergroup variance analysis of calculated lengths for individuals with different life spans at the age of 1 year

\begin{tabular}{|c|c|c|c|c|c|c|c|c|}
\hline \multirow{3}{*}{ Age } & \multicolumn{9}{|c|}{ Reservoirs } \\
\cline { 2 - 9 } & \multicolumn{2}{|c|}{ HS No. 3 } & \multicolumn{2}{c|}{ HS No. 4 } & \multicolumn{2}{c|}{ HS No. 9 } & \multicolumn{2}{c|}{ HS No. 10 } \\
\cline { 2 - 9 } & $\boldsymbol{F}$ & $\boldsymbol{\alpha}$ & $\boldsymbol{F}$ & $\boldsymbol{\alpha}$ & $\boldsymbol{F}$ & $\boldsymbol{\alpha}$ & $\boldsymbol{F}$ & $\boldsymbol{\alpha}$ \\
\hline 1 & 0.790 & 0.573 & 1.417 & 0.259 & 1.107 & 0.366 & 0.510 & 0.793 \\
\hline
\end{tabular}

Here, as we can see, there are no significant differences in the values of linear dimensions in the first year between generations. In this connection, in the von Bertalanffy equation, it is possible to use the data of back calculation without additional processing by the Vaughan-Burton method (Table 9).

Indicators of von Bertalanffy equation, Poly-Munro growth efficiency index and Clark fatness

\begin{tabular}{|c|c|c|c|c|c|c|c|}
\hline \multirow{3}{*}{ Reservoir } & \multicolumn{5}{|c|}{ Variables of equations } & \multirow{3}{*}{$F^{\prime}$} & \multirow{3}{*}{$Q_{C}$} \\
\hline & \multicolumn{3}{|c|}{ VBGE } & \multicolumn{2}{|c|}{ LWR } & & \\
\hline & $\boldsymbol{L}_{\infty}$ & $k$ & $t_{0}$ & $a$ & $b$ & & \\
\hline Reservoir HS No. 3 & 56.0 & 0.066 & -0.46 & 0.040 & 2.90 & 2.32 & 2.82 \\
\hline Reservoir HS No. 4 & 57.0 & 0.070 & -0.38 & 0.024 & 3.05 & 2.36 & 2.81 \\
\hline Reservoir HS No. 9 & 39.2 & 0.128 & -0.09 & 0.034 & 2.91 & 2.29 & 2.54 \\
\hline Reservoir HS No. 10 & 51.4 & 0.079 & -0.39 & 0.016 & 3.12 & 2.32 & 2.36 \\
\hline
\end{tabular}

According to indicators of the von Bertalanffy equation, only the grouping from the reservoir of HS No. 9 is distinguished (Table 9). It also has the lowest growth efficiency index. The highest index $F^{\prime}$ is typical for the sample from the reservoir of HS No. 4.
Poly-Munro index and power exponent of LWR equation change independently of the Clark fatness coefficient which has a pronounced seasonality.

Calculated weight of the trunk, although it seems large (Table 10), is not unattainable for tench.

Table 10

Calculated (theoretical) weight growth of a tench

\begin{tabular}{|c|c|c|c|c|c|c|c|c|c|c|c|c|}
\hline \multirow{2}{*}{ Reservoirs } & \multirow{2}{*}{$\boldsymbol{w}_{\infty}$} & \multicolumn{11}{|c|}{ Calculated trunk weight, $g$} \\
\hline & & 1 & 2 & 3 & 4 & 5 & 6 & 7 & 8 & 9 & 10 & 11 \\
\hline HSNo. 3 & 2425 & 5 & 19 & 46 & 88 & 144 & 214 & 297 & 392 & 497 & 610 & 731 \\
\hline HS No. 4 & 3251 & 4 & 18 & 47 & 94 & 159 & 242 & 341 & 457 & 585 & 725 & 874 \\
\hline HS No. 9 & 1034 & 4 & 21 & 56 & 107 & 170 & 244 & 323 & 405 & 488 & 569 & 648 \\
\hline HS No. 10 & 3521 & 3 & 14 & 38 & 76 & 128 & 195 & 274 & 365 & 465 & 573 & 687 \\
\hline
\end{tabular}

At the same time, it is not necessary to consider such sizes in conjunction with a real chance to achieve them. These "numbers" serve only as a certain indica- tor of the weight growth potential of a group of individuals, the same as $L_{\infty}$ in linear growth. 
This calculation method shows a greater potential (in terms of $w_{\infty}$ ) for the tench from the reservoirs of HS No. 4 and 10 but the increased rates are only for the grouping from the reservoir of HS No. 4. Logically, it follows from this that the life cycle of the tench from the tenth hydrosystem is longer, and from the third - shorter. But, it will be even shorter for the tench from the reservoir of HS No. 9 with their low $w_{\infty}$ and comparable weight growth.

Available data on number and biomass of the harvestable stock in 2011-2016 show its high abundance in the reservoir of HS No. 9-2.9 kg/ha of the commercial part of the population. Groups from the reservoirs of HS No. 3 and 4 are characterized by indicators that are less than $1 \mathrm{~kg} / \mathrm{ha}$, and the tench from the reservoir of HS No. 10 is characterized as less than $0.5 \mathrm{~kg} / \mathrm{ha}$.
These data, to some extent, can explain the characteristics of the growth of tench in reservoirs.

\section{Results discussion}

In general, based on the above, a very ambiguous picture emerges. Difference in the theses made based on the results of the back calculation and calculation of the von Bertalanffy equation suggests that these methods reveal processes occurring in groups that are different in nature. If in relation to the back calculation we can talk about the growth rates, then in relation to von Bertalanffy equation - about some kind of conditional "productivity" or conditional "success". Difference in the evaluation of appearance of the similarity analysis of samples by hierarchical clustering (Table 11).

Table 11

Matrix of sample closeness (square of Euclidean distance)

\begin{tabular}{|c|c|c|c|c|c|c|c|c|}
\hline \multirow{3}{*}{ Reservoirs } & \multicolumn{8}{|c|}{ Groups of parameters } \\
\cline { 2 - 9 } & \multicolumn{2}{|c|}{ Von Bertalanffy Growth Equation (without $\boldsymbol{L}_{\infty}$ ), LWR, $\boldsymbol{F}^{\prime}$} & \multicolumn{3}{c|}{ Calculated lengths from 1 to 9 years } \\
\cline { 2 - 9 } & Hydrosystem No. 3 & HS No. 4 & HS No. 9 & HS No. 10 & Hydrosystem No. 3 & HS No. 4 & HS No. 9 & HS No. 10 \\
\hline HS No. 3 & - & 0.031 & 0.142 & 0.054 & - & 6.200 & 15.800 & 4.270 \\
\hline HS No. 4 & 0.031 & - & 0.112 & 0.007 & 6.200 & - & 4.460 & 1.550 \\
\hline HS No. 9 & 0.142 & 0.112 & - & 0.138 & 15.800 & 4.460 & - & 3.910 \\
\hline HS No. 10 & 0.054 & 0.007 & 0.138 & - & 4.270 & 1.550 & 3.910 & - \\
\hline
\end{tabular}

The central group represented by individuals from the reservoirs of HS No. 4 and 10 shows greater similarity in one case - with a sample from the reservoir HS No. 3, in the other - with a sample from the reservoir of HS. No. 9. Hence, in general, the dualism of evaluation and the problem of making a decision arise.

Question of the ratio of high growth rates and its effectiveness becomes relevant. In any case, in natural populations, growth will have adaptive functions and will be the most acceptable in this situation. Of course, based on different approaches, it is possible to compare in which reservoir the growth rate is higher, for example, to assess the ecological state of populations or habitat.

The question of effectiveness of growth arises already in the context of use of populations in fisheries, and it will be most acute in artificial systems and "systems under influence" where energy flows are more or less controlled directly or through certain efforts. Taking into account the fact that all fishery reservoirs are similar "systems under the influence" to one degree or another (mainly through fishing), it is necessary to take into account factors and create conditions for more efficient use of energy flows in cenoses. In particular, it is necessary to solve such a private issue: Which is more effective: high growth rates or prolonged age range? It seems that rapid growth is more acceptable for the fishery. But if, for example, we are not dealing with the main commercial species, as in the case of a tench, is it not more effective to have a population with less rapid growth, but a more extended age range? Its individuals reach the same size albeit for a longer time but have less impact on the annually self-reproducing food base leaving resources for the main commercial species. In this regard, questions will already arise about the use of fishing gear of certain characteristics, the intensity and timing of this fishing, and a number of others. It is obvious that it is necessary to solve this dilemma of growth efficiency in each specific case separately.

In the described case, the tench from the reservoir of HS No. 9 exhibit the highest rates of linear growth over a sufficiently long time range. At the same time, their growth efficiency indices are the lowest. The latter is determined by a faster drop in increments which lowers the calculated asymptotic length $L_{\infty}$ and then the Poly-Munro coefficient. The rates of theoretical weight growth are also low which is determined by the worst growth allometry system (the ratio of variables in LWR equation). Individuals from this reservoir in younger and middle age quite often reliably outperform their peers from HS No. 3 in natural increments, for example (Figure) 


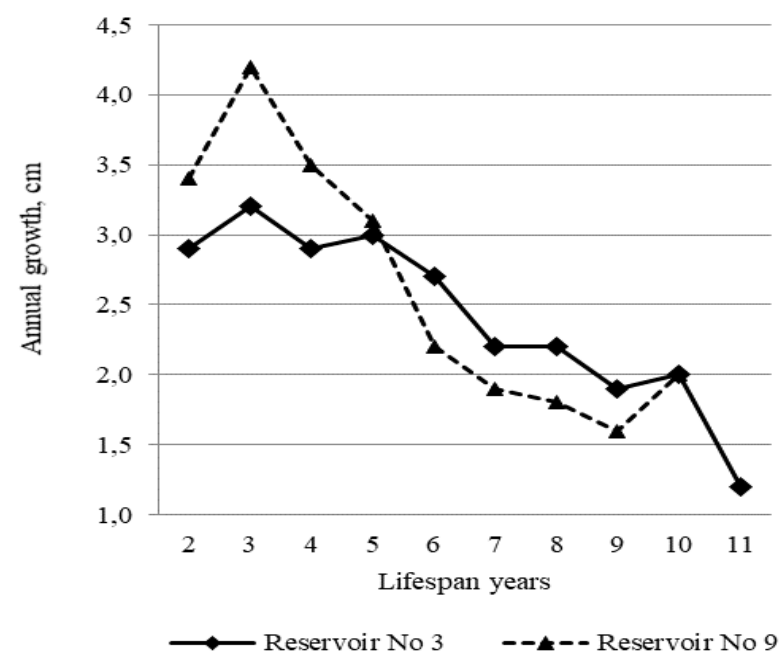

Natural growth of tench from reservoirs of HS No. 3 and 9 of K. Satpayev Canal

But then, they begin to give way strongly often also at a statistically reliable level. In this comparison pair, high growth rates in the early stages (by the age of puberty and 1-2 years older) are accompanied by a shorter age range.

In general, it is worth recognizing that the most successful growth pattern has individuals from the reservoir of HS No. 3. The tench grows worse in the reservoir of HS No. 9. Such a short age range is not beneficial for fishery and for the group as a whole. In the latter case, an undeveloped age range ensures intensity of reproduction due to the lower fertility of small fractions, compared with large individuals [1]. The relatively low "productivity" of growth is also characteristic of the tench from the reservoir of HS No. 10. In principle, for such an assessment at the primary stage, we can focus on Poly-Munro index.

Aggregate of individuals from the reservoir of HS No. 4 probably did not receive a full assessment which follows from characteristics of the gains and is confirmed by VBGE indicators and growth efficiency index. The growth of this grouping is most likely adequate for individuals from the reservoir of HS No. 3 .

The question of initial prerequisites for growth and influence of factors of various nature on it has already been touched upon above. It is worth mentioning that the four more fully considered groupings live in reservoirs that are more or less similar in their conditions. As noted above, the hydrochemical regime in these reservoirs is relatively similar. Hydromorphological parameters and temperature regime of reservoirs are also approximately the same. The biotic environment in ichthyocenosis is composed of approximately the same species. The state of food base by main components (zoobenthos, soft underwater vegetation) also rated as approximately equal.

At the same time, fishing cannot be regarded as the same. There is no fishing in the reservoirs of Pavlodar part (HS No. 3 and 4) although poaching is probably present. In the reservoirs of Karaganda part (HS No. 9 and 10), there is quite active fishing including this species. In the reservoir of HS No. 9, the main concentrations of tench are located between the outlet of main canal and the mouth of Muzdybulak River. In fact, the tench in this reservoir, as already noted above, is the most commercially profitable fish. Accordingly, it is under constant commercial pressure here throughout the growing season. Stationary nets with an average mesh pitch $(40-60 \mathrm{~mm})$ are used. In the reservoir of HS No. 10, the production of tench goes more seasonally for a short period in June-July, in other months of the year it is withdrawn at the level of by-catch. For this case, nets with $60 \mathrm{~mm}$ mesh and higher are used for its catching.

As a result we have a picture of some influence of the presence and selectivity of fishing on the growth rates of tench in these reservoirs. At the same time it is worth remembering that the "launch of fishing" has a certain negative impact including on the growth rates of fish [36]. In the case of Pavlodar hydrosystem, there is no "launch" in the full sense of this phenomenon since fishing was stopped relatively recently and at that time the species did not reach the limit in developing its niche in the hydrobiocenosis.

For the reservoir of HS No. 9, where the tench is the most valuable object of fishing, this situation is not optimal. It is quite possible that it is necessary to intensify the fishing load for a period approximately equal to one generation (3 years) with subsequent fixation of fishing mortality at a level much lower than during the period of increased withdrawal. In the reservoir of HS No. 10, where the main objects of catching are completely different species and the relative number of tench is extremely low, the tench fishing will always be no more than the level of by-catch. 
At the same time, the number (biomass) of the species should still be regarded as a basic indicator (of a higher level and more general) for the formation of growth rates. It is associated both with the food supply, catching, fishing and higher-order experiments, as well as with a large number of other factors.

\section{Conclusion}

The tench in the canal reservoirs forms populations that differ in their productivity and growth rates. Sexual and generational variability is virtually absent. The tench growth in the reservoirs of K. Satpayev canal is sufficiently channeled - the continuity of its pace is clearly visible over the years of its life. At the same gains. R. Lee phenomenon was not noted in the course of research. Variables of the von Bertalanffy equation show a high asymptotic length for three samples out of four studied. This was also reflected in Poly-Munro growth efficiency coefficient. Theoretically calculated weight growth using Hilborn-Waters method showed time, such a relationship is weak enough for natural

the need to include both asymptotic value and rate of mass gain in the estimate.

Formally, the tench from the reservoir of HS No. 9 differs in the highest rates of linear growth. At the same time, the productivity of their growth scheme is quite low which is estimated by many related indicators: variables of the von Bertalanffy equation, efficiency index, calculated weight growth, fatness coefficient and length of the age. The most productive growth is shown by individuals from the reservoir of HS No. 3 that have the longest life expectancy. At the same time, it is worth noting that any assessment of growth is quite dualistic and cannot be definitive.

In the reservoirs of the canal, due to the specifics of its functioning, there are more or less the same conditions for the existence of tench populations. The main limiting factor for the growth rate, in our opinion, will be the abundance of species in the reservoir and the trophic factors associated with it, with a certain influence of natural and commercial mortality.

\section{References}

1. Asylbekova S. Zh., Krainiuk V. N. Lin' Tinca tinca (1., 1758) vodokhranilishch kanala im. K. Satpaeva [Tench Tinca tinca (1., 1758) in reservoirs of K. Satpayeva canal]. Vestnik Astrakhanskogo gosudarstvennogo tekhnicheskogo universiteta. Seriia: Rybnoe khoziaistvo, 2013, no. 1, pp. 29-34.

2. Serov N. P. Ichthyofauna of the Kamysh-Samara and Kushum lakes. Collection of works on ichthyology and hydrobiology. Alma-Ata, Publishing House of the Academy of Sciences of the Kazakh SSR, 1959. Iss. 2. Pp. 152-175.

3. Dushin A. I., Voinova T. V. Fish fauna of the lakes of the Mordovian Reserve. Works of the Mordovian State Nature Reserve named after P. G. Smidovich, 1970, no. 5, pp. 171-187.

4. Mitrofanov V. P., Dukravets G. M., Sidorova A. F., Soloninova L. N., Markova E. L., Mitrofanov I. V., Bashunova N. N. Kazakhstan Fish. Alma-Ata, Science, 1987. Vol. 2. 200 p.

5. Dyatlov M. A. Fish of Lake Ladoga. Petrozavodsk, Publishing house of KarSC RAS, 2002. 281 p.

6. Gerassimov Yu. V., Zelenetsky N. M. Tench. Fish of the Rybinsk reservoir: population dynamics and ecology. Yaroslavl, Filigree, 2015. Pp. 296-299.

7. Krainyuk V. N. Back calculation of the growth of tench Tinca tinca (L., 1758) (Cyprinidae) from two reservoirs of Karaganda region. Fish farming and fisheries, 2020, no. 11 , pp. 20-31. DOI:10.33920/sel-09-2011-02

8. Weatherley A. H. Some features of the biology of the tench Tinca tinca (Linnaeus) in Tasmania. J. Anim. Ecol., 1959, vol. 28, no. 1, pp. 73-87.

9. Kennedy M., Fitzmaurice P. The Biology of the Tench Tinca tinca (L.) in Irish Waters. Proc. Royal Irish Acad. Section B: Biological, Geological, and Chemical Science, 1970, vol. 69, pp. 31-82.

10. O'Maoileidigh N., Bracken J. J. Biology of tench, Tinca tinca (L.), in an Irish lakes. Aquaculture and Fisheries Management, 1989, vol. 20, pp. 199-209.

11. Altındağ A., Yiğit S., Ahiska S., Özkurt Ş. The Growth Features of Tench (Tinca tinca L., 1758) in the Kesikköprü Dam Lake. Tr. J. of Zoology, 1998, no. 22, pp. 311-318.
12. Benzer S. S., Gül A., Yilmaz M. Growth properties of tench (Tinca tinca L., 1758) living in Kapulukaya dam lake. Eylül, 2010, vol. 18, no. 3, pp. 839-848.

13. Pompei L., Franchi E., Giannetto D., Lorenzoni M. Growth and reproductive properties of Tench, Tinca tinca Linnaeus, 1758, in Trasimeno Lake (Umbria, Italy). Knowl. Managt. Aquatic Ecosyst., 2012, no. 406, 7 p. DOI: $10.1051 / \mathrm{kmae} / 2012024$

14. Pravdin N. F. Fish Study Guide. Moscow, Food industry Publ., 1966. 376 p.

15. Sini A. I., Meunier F. J., Francillon-Vieillot H. Comparison of scales, opercular bones, and vertebrae to determinate age and population structure in tench, Tinca tinca (L., 1758) (Piscers; Teleostei). Israel Journal of Zoology, 1999, vol. 43, no. 4, pp. 453-465. DOI: 10.1080/00212210.1999. 10689011

16. Francis R. Back-calculation of fish length: a critical review. J. Fish. Biol., 1990, vol. 36, no. 6, pp. 883-902.

17. Dgebuadze Yu. Yu. Ecological patterns of fish growth variability. Moscow, Science Publ., 2001. 276 p.

18. Mina M. V., Klevezal G. A. Growth of animals. Moscow, Science Publ., 1976. 291 p.

19. Ilmast N. V. Introduction to ichthyology. Petrozavodsk, Publishing house of KarSC RAS, 2005. 148 p.

20. Milovanov A. I. Commercial ichthyology. Lecture growth in fish and invertebrates. Fishbyte, 1984, no. 2, p. 21.

22. Vaughan D. S., Burton M. L. Estimation of von Bertalanffy growth parameters in the presence of size-selective mortality: A simulated example with Red Grouper. Transac. 10.1577/1548-8659(1994) 123<0001: EOVBGP >2.3.CO;2

23. Hilborn R., Walters J. C. Quantitative fisheries stock assessment, choice, dynamics and uncertainty. New York, Chapman and Hall, 1992. 570 p.

24. Froese R. Cube law, condition factor and weightlength relationships: history, meta-analysis and recommendations. J. Appl. Ichthyol., 2006, vol. 22, no. 4, pp. 241-253. notes. Kerch, FSBEE OF HE “KSMTU”, 2019. 109 p.

21. Pauly D., Munro J. L. Once more on the comparison of Amer. Fish. Soc., 1994, vol. 123, no. 1, pp. 1-8. DOI: 
25. Kotlyar O. A. Methods of fisheries research (ichthyology). Moscow, Ekon-inform Publ., 2013. 222 p.

26. Plokhinsky N. A. Biometrics. Moscow, Moscow State University, 1970. $367 \mathrm{p}$.

27. Korosov A. V., Gorbach V. V. Computer processing of biological data. Petrozavodsk, Publishing house of PSU, $2007.76 \mathrm{p}$.

28. Byul A., Cefel P. SSPS: The Art of information processing. Saint-Petersburg, Diasoftyup, 2005. 608 p.

29. Henderson B. A., Collins N., Morgan G. E., Vaillancourt A. Sexual size dimorphism of walleye (Stizostedion vitreum vitreum). Can. J. Fish. Aquat. Sci., 2003, vol. 60, no. 11 , pp. 1345-1352. DOI: 10.1139/f03-115.

30. Marshall M. D., Maceina M. J., Holley M. P. Age and Growth Variability between Sexes of Three Catfish Species in Lake Wilson, Alabama. North American Journal of Fisheries Management, 2009, vol. 29, iss. 5, pp. 1283-1286. DOI: 10.1577/M08-258.1.

31. Sandip B., Toshiharu I., Takeshi M., Masato H., Gersende M., Chiemi M. Differences between male and female growth and sexual maturation in tilapia (Oreochromis mossambicus). Kathmandu Univer. Journ. of Sci., Engineer. and Technol., 2012, vol. 8, no. 11, pp. 57-65.

32. Nikolsky G. V. Dynamics of commercial fish populations. Moscow, Science Publ., 1965. 382 p.

33. Folkvord A., Jørgensen C., Korsbrekke K., Nash R. D. M., Nilsen T., Skjæraasen J. E. Trade-offs between growth and reproduction in wild Atlantic cod. Can. J. Fish. Aquat. Sci., 2014, vol. 71, iss. 7, pp. 1106-1112. DOI: dx.doi.org/10. 1139/cjfas-2013-0600.

34. Nakayama S., Rapp T., Arlinghaus R. Fast-slow life history is correlated with individual differences in movements and prey selection in an aquatic predator in the wild. J. Anim Ecol., 2017, no. 86, pp. 192-201. DOI: https://doi.org/10.1111/ 1365-2656.12603.

35. Barneche D. R., Robertson D. R., White C. R., Marshall D. J. Fish reproductive-energy output increases disproportionately with body size. Science, 2018, vol. 360, iss. 6389, pp. 642-645. DOI: 10.1126/science.aao6868.

36. Kudersky L. A. Dynamics of herds of commercial fish of inland reservoirs. Moscow, Science Publ., 1991. 151 p.

\section{Список источников}

1. Асылбекова С. Ж., Крайнюк В. Н. Линь Тinca tinca (1., 1758) водохранилищ канала им. К. Сатпаева // Вестн. Астрахан. гос. техн. ун-та. Сер.: Рыбное хозяйство. 2013. № 1. C. 29-34.

2. Serov N. P. Ichthyofauna of the Kamysh-Samara and Kushum lakes // Collection of works on ichthyology and hydrobiology. Alma-Ata: Publishing House of the Academy of Sciences of the Kazakh SSR, 1959. Iss. 2. Pp. 152-175.

3. Dushin A. I., Voinova T. V. Fish fauna of the lakes of the Mordovian Reserve // Works of the Mordovian State Nature Reserve named after P. G. Smidovich. 1970. № 5. P. 171-187.

4. Mitrofanov V. P., Dukravets G. M., Sidorova A. F., Soloninova L. N., Markova E. L., Mitrofanov I. V., Bashunova N. N. Kazakhstan Fish. Alma-Ata: Science, 1987. V. 2. 200 p.

5. Dyatlov M. A. Fish of Lake Ladoga. Petrozavodsk: Publishing house of KarSC RAS, 2002. 281 p.

6. Gerassimov Yu. V., Zelenetsky N. M. Tench // Fish of the Rybinsk reservoir: population dynamics and ecology. Yaroslavl: Filigree, 2015. P. 296-299.

7. Krainyuk $V$. N. Back calculation of the growth of tench Tinca tinca (L., 1758) (Cyprinidae) from two reservoirs of Karaganda region // Fish farming and fisheries. 2020. N. 11. P. 20-31. DOI:10.33920/sel-09-2011-02.

8. Weatherley A. H. Some features of the biology of the tench Tinca tinca (Linnaeus) in Tasmania // J. Anim. Ecol. 1959. V. 28. N. 1. P. 73-87.

9. Kennedy M., Fitzmaurice P. The Biology of the Tench Tinca tinca (L.) in Irish Waters // Proc. Royal Irish Acad. Section B: Biological, Geological, and Chemical Science. 1970. V. 69. P. 31-82.

10. O'Maoileidigh N., Bracken J. J. Biology of tench, Tinca tinca (L.), in an Irish lakes // Aquaculture and Fisheries Management. 1989. V. 20. P. 199-209.

11. Altında $\breve{g}$ A., Yiğit S., Ahiska S., Özkurt Ş. The Growth Features of Tench (Tinca tinca L., 1758) in the Kesikköprü Dam Lake // Tr. J. of Zoology. 1998. N. 22. P. 311-318.

12. Benzer S. S., Gül A., Yilmaz M. Growth properties of tench (Tinca tinca L., 1758) living in Kapulukaya dam lake // Eylül. 2010. V. 18. N. 3. P. 839-848.

13. Pompei L., Franchi E., Giannetto D., Lorenzoni M. Growth and reproductive properties of Tench, Tinca tinca
Linnaeus, 1758, in Trasimeno Lake (Umbria, Italy) // Knowl. Managt. Aquatic Ecosyst. 2012. N. 406. 7 p. DOI: $10.1051 / \mathrm{kmae} / 2012024$.

14. Pravdin N. F. Fish Study Guide. M.: Food industry, 1966. $376 \mathrm{p}$.

15. Sini A. I., Meunier F. J., Francillon-Vieillot H. Comparison of scales, opercular bones, and vertebrae to determinate age and population structure in tench, Tinca tinca (L., 1758) (Piscers; Teleostei) // Israel Journal of Zoology. 1999. V. 43. N. 4. P. 453-465. DOI: 10.1080/00212210.1999. 10689011 .

16. Francis $R$. Back-calculation of fish length: a critical review // J. Fish. Biol. 1990. V. 36. N. 6. P. 883-902.

17. Dgebuadze Yu. Yu. Ecological patterns of fish growth variability. M.: Science, 2001. 276 p.

18. Mina M. V., Klevezal G. A. Growth of animals. M.: Science, 1976. 291 p.

19. Ilmast $N$. $V$. Introduction to ichthyology. Petrozavodsk: Publishing house of KarSC RAS, 2005. 148 p.

20. Milovanov A. I. Commercial ichthyology. Lecture notes. Kerch: FSBEE OF HE "KSMTU”, 2019. 109 p.

21. Pauly D., Munro J. L. Once more on the comparison of growth in fish and invertebrates // Fishbyte. 1984. N. 2. P. 21.

22. Vaughan D. S., Burton M. L. Estimation of von Bertalanffy growth parameters in the presence of size-selective mortality: A simulated example with Red Grouper // Transac. Amer. Fish. Soc. 1994. V. 123. N. 1. P. 1-8. DOI: 10.1577/1548-8659(1994) 123<0001: EOVBGP >2.3.CO;2

23. Hilborn R., Walters $J$. C. Quantitative fisheries stock assessment, choice, dynamics and uncertainty. New York: Chapman and Hall, 1992. 570 p.

24. Froese $R$. Cube law, condition factor and weight-length relationships: history, meta-analysis and recommendations // J. Appl. Ichthyol. 2006. V. 22. N. 4. P. 241-253.

25. Kotlyar O. A. Methods of fisheries research (ichthyology). M.: Ekon-inform, 2013. 222 p.

26. Plokhinsky N. A. Biometrics. M.: Moscow State University, $1970.367 \mathrm{p}$.

27. Korosov A. V., Gorbach V. V. Computer processing of biological data. Petrozavodsk: Publishing house of PSU, 2007. $76 \mathrm{p}$. 
28. Byul A., Cefel P. SSPS: The Art of information processing. Saint-Petersburg: Diasoftyup, 2005. 608 p.

29. Henderson B. A., Collins N., Morgan G. E., Vaillancourt A. Sexual size dimorphism of walleye (Stizostedion vitreum vitreum) // Can. J. Fish. Aquat. Sci. 2003. V. 60. N. 11. P. 1345-1352. DOI: 10.1139/f03-115.

30. Marshall M. D., Maceina M. J., Holley M. P. Age and Growth Variability between Sexes of Three Catfish Species in Lake Wilson, Alabama // North American Journal of Fisheries Management. 2009. V. 29. Iss. 5. P. 1283-1286. DOI: $10.1577 / \mathrm{M} 08-258.1$.

31. Sandip B., Toshiharu I., Takeshi M., Masato H., Gersende M., Chiemi M. Differences between male and female growth and sexual maturation in tilapia (Oreochromis mossambicus) // Kathmandu Univer. Journ. of Sci., Engineer. and Technol. 2012. V. 8. N. 11. P. 57-65.

32. Nikolsky G. $V$. Dynamics of commercial fish popula-
Vladimir N. Krainyuk - Head of Reference Point of Karaganda City; Fisheries Research and Production Center LLP, Northern branch; Republic of Kazakhstan, Karaganda region, Osakarovka village, Gagarin street, 2; krainyuk@fishrpc.kz

Saule Zh. Assylbekova - Doctor of Biological Sciences, Assistant Professor; Deputy General Director; Research and Production Centre of Fisheries, Ltd., Republic of Kazakhstan, Almaty, Suyunbay avenue,89A; assylbekova@mail.ru

Azis V. Shutkarayev - Branch Director; Republic of Kazakhstan, Nur-Sultan, Kenessary street, 43; azis-62@mail.ru
33. Folkvord A., Jørgensen C., Korsbrekke K., Nash R. D. M., Nilsen T., Skjceraasen J. E. Trade-offs between growth and reproduction in wild Atlantic cod // Can. J. Fish. Aquat. Sci. 2014. V. 71. Iss. 7. P. 1106-1112. DOI: dx.doi.org/10.1139/ cjfas-2013-0600.

34. Nakayama S., Rapp T., Arlinghaus R. Fast-slow life history is correlated with individual differences in movements and prey selection in an aquatic predator in the wild // J. Anim Ecol. 2017. N. 86. P. 192-201. DOI: https://doi. org/10.1111/1365-2656.12603.

35. Barneche D. R., Robertson D. R., White C. R., Marshall $D$. J. Fish reproductive-energy output increases disproportionately with body size // Science. 2018. V. 360. Iss. 6389. P. 642-645. DOI: 10.1126/science.aao6868.

36. Kudersky L. A. Dynamics of herds of commercial fish of inland reservoirs. M.: Science, 1991. $151 \mathrm{p}$.

\section{Information about authors / Информация об авторах}

Владимир Николаевич Крайнюк - заведующий опорным пунктом в г. Караганда; Научно-производственный центр рыбного хозяйства, Северный филиал; Республика Казахстан, Карагандинская область, п. Осакаровка, ул. Гагарина, 2; krainyuk@fishrpc.kz

Сауле Жангировна Асылбекова - доктор биологических наук, доцент; заместитель генерального директора; ТОО «Научно-производственный центр рыбного хозяйства»; Республика Казахстан, Алматы, проспект Суюнбая, 89, A; assylbekova@mail.ru

Азис Васильевич Шуткараев - директор филиала; Научно-производственный центр рыбного хозяйства, Северный филиал; Республика Казахстан, Нур-Султан, ул. Кенесары, 43; azis-62@mail.ru 